\title{
Renewing the resource base in line with the dynamic capabilities view: a key to sustained competitive advantage in the IT industry*
}

\author{
Lidija Breznik, Matej Lahovnik ${ }^{* *}$
}

The purpose of this paper is to indicate that firms which renew their resource base in line with the dynamic capabilities view can generate and sustain a competitive advantage and thus the related firm performance. In order to investigate the relationships involved, in-depth interviews were conducted in six representative IT firms. The results suggest that firms with a stronger commitment to deploying dynamic capabilities are more successful and hold the potential for a sustained competitive advantage. We also found that innovation capability, managerial capability and human resource capability are the most relevant capabilities that allow firms to successfully adapt to a changing environment and the highly demanding IT market.

Das Ziel dieses Artikels ist es zu bestätigen, dass Unternehmen, deren Ressourcenentwicklung auf dem "Dynamic Capabilities" beruht, einen Wettbewerbsvorteil erlangen und halten, sowie auch ihre Unternehmensleistung steigern können. Um die grundlegende Forschungsfrage zu bestätigen, haben wir eine Serie von tiefgehenden Interviews in sechs repräsentativen IT-Unternehmen durchgeführt. Bei der Studie wurde festgestellt, dass Unternehmen, die sich stärker auf den "Dynamic Capabilities" konzentrieren, erfolgreicher sind und auch ihr Potenzial, den Wettbewerbsvorteil zu halten, höher ist. Die Studie hat außerdem ergeben, dass die Innovations- und Führungsfähigkeit, sowohl auch die Fähigkeit im Umgang mit Humanressourcen, die Schlüsselfähigkeiten sind, die den Unternehmen ermöglichen, sich dem ständig wandelnden Umfeld im IT-Bereich anzupassen.

Key words: dynamic capabilities, competitive advantage, information technology (IT) industry, case study (JEL: L16, Q56)

\footnotetext{
* Manuscript received: 03.04.13, accepted: 23.01 .14 (2 revisions)

** Lidija Breznik, PhD, Teaching Assistant, Faculty of Economics, University of Ljubljana, Slovenia. Main research interests: strategic management, innovation management. Corresponding E-mail: lidija.breznik@, ef.uni-lj.si

Matej Lahovnik, PhD, Full Professor, Faculty of Economics, University of Ljubljana, Slovenia. Main research interests: strategic management, corporate governance, mergers, acquisitions. Corresponding E-mail: matej.lahovnik@ef.uni-lj.si
} 


\section{Introduction}

Managing firms has never been so difficult, especially for information technology (IT) firms operating in a high velocity environment. In such an environment, firms experience great uncertainty and intensive competition. Consequently, to be able to survive in such conditions firms need to renew their resource base as their environment changes. The dynamic capabilities view (DCV) has emerged as an attempt to untangle the complex problem of sustainable competitive advantage in today's dynamic environment (Teece et al. 1997; Eisenhardt/Martin 2000). The underlying assumption is that firms which are able to sense and then seize new opportunities and, further, reconfigure their resources and capabilities in line with recognised opportunities and environmental change can create and sustain a competitive advantage (Teece 2009). The DCV has received a lot of attention in recent years, although the outcome is a complex, sometimes confusing body of research with limited empirical studies. The main reason for the modest empirical evidence might be the apparent dominance of quantitative studies, which may infer the presence of dynamic capabilities by examining a firm's performance outcomes (Ambrosini/Bowman 2009). Arend and Bromley (2009:87) argue that, if we do not develop a theoretical foundation, the field of strategic management may move away from the DCV. Ambrosini and Bowman (2009) propose that fine-grained case studies of firms able to sustain a competitive advantage over time in dynamic environments can offer insights into the dynamic capabilities field.

There are two motivations for conducting this research. First, the central focus and challenge in business economics is how to attain and sustain a competitive advantage. To sustain their competitive advantage firms need to renew their resource base as their environment changes. The relatively static nature of earlier well-known perspectives in the strategic management field largely explains why new perspectives have emerged. The latest approach seeking to extend previous views is the DCV that apparently can be useful for strategic management as a field of study as well as for practitioners, and therefore calls for a deeper understanding. Second, we so far have little evidence on which to base suggestions for how to build dynamic capabilities. The literature on dynamic capabilities is currently imbued with conceptual and theoretical debates instead of focusing on empirical testing. Therefore, with our research we are taking a step towards accumulating enough case-based data to create the possibility to better understand the DCV's importance as a source of competitive advantage.

The paper's main purpose is to recognise dynamic capabilities as a source of competitive advantage in the IT industry. It focuses on the following key research question: Are firms that renew their resource base in line with the DCV able to sustain a competitive advantage and thus the related firm performance? In line with this vital research question, the objectives of this paper are: (1) to identify relevant capabilities in IT firms in general and, from a dynamic capa- 
bilities viewpoint, their sensing, seizing and reconfiguring capabilities; and (2) to investigate the level at which each individual dynamic capability is deployed, and to link this to firm performance. In order to examine the relationships involved, in-depth interviews were conducted in six representative firms in the IT industry. Due to that industry's specific nature, IT firms represent a suitable context to create and validate our research model. In addition, the DCV is particularly relevant to markets exposed to rapid technological change and strong international competition (Teece 2009:156). This paper highlights the promising avenues and potential offered by the DCV that encourages further development. Moreover, it empirically contributes to the emerging work on dynamic capabilities through its detailed cross-case study investigation.

Our paper is distinguished by its focus on dynamic capabilities through detailed cross-case studies of firms operating in a highly demanding market. The paper adds to a better understanding of dynamic capabilities by exploring their deployment and development through their three components: sensing, seizing and reconfiguring capabilities. Our study also contributes by studying relevant firm capabilities from the dynamic capabilities perspective and points out how important it is to understand that simply possessing and developing the 'right' resource base but without exploiting and adapting it in line with dynamic capabilities is not enough to sustain a competitive advantage. The use of qualitative analysis enables us to provide insights into how dynamic capabilities are deployed. In order to understand the manifestations of sensing, seizing and reconfiguring capabilities, we present an overview of practices that underpin dynamic capabilities in Beta, a case-study firm with an outstanding performance (Appendix 1). We believe this overview of practices could encourage managers, especially in IT firms, to contemplate and understand how this may be useful in practice. Finally, our research reveals that some capabilities are more dominant in the process of creating and sustaining a competitive advantage, although all of the studied capabilities are relevant and have to be developed simultaneously. We propose that taking such a perspective is a contribution to narrowing this knowledge gap.

\section{Literature review (theoretical foundations)}

The fundamental question in the strategic management field is how firms achieve and sustain a competitive advantage. Competitive advantage (Porter 1985) is a dominant concept in the strategic management research with a long and varied history, and the most influential mechanism for explaining the persistence of an economic performance. Since the average period in which firms can sustain a competitive advantage has been decreasing over time (Wiggins/Ruefli 2005), the issue of maintaining such an advantage has become a critical concern of both academics and practitioners. To retain a competitive advantage firms need to renew their stock of valuable resources as their external environment 
changes, with dynamic capabilities as an approach allowing firms to effect these ongoing changes. The DCV is the latest perspective trying to explain and guide firms on how they can achieve and sustain a competitive advantage. The publication by Teece et al. (1997) is recognised as the first seminal paper on the notion of dynamic capabilities. The paper has its roots in the earlier working papers of Teece and Pisano (1994), and Teece, Pisano and Shuen (1990). Evidently, the paper triggered a growing body of articles, namely more than 1,534 from 1997 to 2007 (Barreto 2010), and over 1,900 citations by December 2009 (DiStefano et al. 2010). Such interest in this topic has added to the richness of the field and created much debate. However, this debate has generally focused on explaining the nature of dynamic capabilities and further exploring their effects and consequences (Easterby-Smith et al. 2009). Consequently, the field remains mostly conceptual and largely focuses on foundation-level issues (Helfat/Peteraf 2009). Extensive literature reviews in recent years (e.g. Zahra et al. 2006; Wang/ Ahmed 2007; Ambrosini/Bowman 2009; Baretto, 2010) have not shown much progress as the field is still overflowing with a disconnected body of research. In addition, the DCV has received a lot of criticism (like other previous approaches such as the resource-based view (RBV) (Wernerfelt 1984; Barney 1991)) for being fuzzy and tautological (e.g. Winter 2003) with little empirical support (Newbert 2007; Ambrosini et al. 2009). We propose that, if the dynamic capabilities view is useful for strategic management as a field of study and, of course, for practitioners, then it needs to be fully researched.

The dynamic capabilities view encapsulates some ideas from earlier work and perspectives, especially those built on evolutionary ideas. According to the literature review, scholars like Schumpeter (1934), Penrose (1959), Cyert and March (1963), Winter (1975), Nelson and Winter (1982) made significant contributions to the evolutionary models of economic change, and to the behavioural theory of the firm. These ideas have had an important impact on further theory development regarding how firms behave and evolve. Accordingly, understanding firms' behaviour and evolution helps scholars express a firm's strategy in a dynamic setting (Pierce/Teece 2005). The DCV can, in fact, be understood as the "new behavioural theory of the firm" (Augier/Teece 2009:413) that extends the $\mathrm{RBV}$, one of the most dominant frameworks in the strategic management literature (Zott 2003). While the intention of the DCV was to extend the RBV, mainly because of its largely static nature (Priem/Butler 2001), the DCV also shares some parallels with the core competence perspective (Prahalad/Hamel 1990) and the knowledge-based view (Grant 1996; Ambrosini/ Bowman 2009). All of these perspectives consider a firm to be a bundle of heterogeneous and pathdependent resources and capabilities that allows it to achieve a sustainable competitive advantage (Ambrosini/Bowman 2009). Accordingly, the DCV develops previous perspectives, especially the RBV, by addressing the importance of the external environment to which resources and capabilities must be aligned. It explicitly acknowledges that firms need to adjust and reconfigure their resource 
base as markets and technologies evolve (Harreld et al. 2007). To study dynamic capabilities and further investigate their relationship with competitive advantage, we have to take an analytical approach. From an analytical perspective, dynamic capabilities can be broken down into three classes, i.e. sensing capability, seizing capability and reconfiguring capability (Teece 2007; 2009). This analytical approach to studying dynamic capabilities as a composition of three capabilities was applied in our research. Therefore, in the next section we present a conceptual model and explain the research approach adopted for our study.

\section{Conceptual model and research approach}

As indicated above, for the purpose of our research we adopt Teece's (2009) breakdown of dynamic capabilities into three classes: a capability to sense opportunities, a capability to seize opportunities and a capability to reconfigure a firm's resource base. The sensing and seizing capabilities are different from reconfiguring capability since the first two capture more fundamental purposes, while the reconfiguring capability is more complex and may even involve a complete business model redesign (Teece 2009:51,215). In that perspective, dynamic capabilities are strategically important and generally costly. Hence, a small mistake (e.g. unfocused sensing) can have a strong, negative impact on a competitive position or a firm's performance. Obviously, dynamic capabilities are costly, especially if we consider their development since they involve a longterm commitment to specialised resources and capabilities (Teece/Pisano 1994; Zollo/Winter 2002; Zahra et al. 2006). Following Teece's (2009) terminology, we now explain the basic meaning of sense, seize and reconfigure capability. To identify opportunities, firms need to continuously scan their environments and search for opportunities that are constantly opening up. Such searching has to be done inside and outside the firm's boundaries. The following activities can be presented as an example of typical activities or practices that comprise sense capabilities: activities in the R\&D process that enable the creation of new or improved knowledge, activities of scanning for new inventors or exploring market needs, and activities that result in understanding technological transformation. When opportunities are sensed, they then need to be seized and their value and potential have to be recognised. The seizing of capabilities underpins the following practices: selecting the 'right' technology or recognising the target customers, recognising the value of non-economic factors in creating a competitive advantage, avoiding decision errors and selecting the firm's boundaries. Teece (2009:206-209) acknowledged that the seizing capability is really about making good decisions under uncertainty and executing these decisions well. Finally, when opportunities are sensed and seized, the next and final step is that they need to be reconfigured. Namely, the successful identification of opportunities must be eventually addressed through new products or services, processes, positions and paradigms (the 4 Ps) (Tidd/Bessant 2009:22). In general, reconfiguring capability means the ability to recombine and reconfigure the resource base to 
address changes and opportunities inside and outside the firm's boundaries. As manifestations of reconfiguring capabilities, several practices can be noted: activities in knowledge management, know-how integration and activities for managing strategic fit (Teece 2009).

Our study focuses on the following key research question: Are firms that renew their resource base in line with the DCV able to sustain a competitive advantage and thus the related firm performance? Our assumption is that the stronger the deployment of dynamic capabilities, the more abilities/advantages a firm has in building and sustaining a competitive advantage, and this results in an improved firm performance. The relationship we apply in our study is: dynamic capabilities $\rightarrow$ competitive advantage $\rightarrow$ firm performance. Still, it has to be acknowledged that the literature discusses different patterns of relationships between dynamic capabilities, competitive advantage and firm performance. In addition, many studies use different operationalisations of the performance measures and this affects the results and conclusions. A common practice when studying firm performance is to only take financial performance into consideration. With its roots in financial indicators, financial performance has for decades been a dominant model in empirical strategy research (Venkatraman/Ramanujam 1986). The comprehensive literature review by Melville et al. (2004) indicates that scholars have employed two main formulations of performance, efficiency and effectiveness, and that ROI, ROA, sales and market share are commonly used metrics. However, financial indicators have their weaknesses and disabilities when it comes to presenting a firm's real strength. To improve the quality of our research, we combine financial indicators with non-financial indicators. This combination of indicators relevant to our research was selected in line with recommendations in the literature.

To answer the main research question, we first analyse the deployment of relevant dynamic capabilities in each case-study firm and then link the level of their deployment of dynamic capabilities with firm performance. Next, we conduct a cross-case analysis to identify the relationship between the level of deployment of dynamic capabilities and firm performance.

As an indicator of a firm's performance we considered the average values of ten selected financial indicators (namely: (1) ROA; (2) ROE; (3) ROS; (4) revenuesto-expenses ratio; (5) sales-to-operating ratio; (6) shareholders' funds to assets; (7) value added per employee; (8) sales growth; (9) labour productivity; (10) average salary income per employee) and six non-financial indicators (namely: (1) percentage of loyal customers; (2) firm employment growth; (3) firm parttime employment growth; (4) turnover rate; (5) share of expenses on training and education; and (6) share of expenses on R\&D) for the last five business years (2006-2010) as well as management self-evaluation reports (i.e. management perception of strategy goals and performance achievement). Based on the literature review, six capabilities were recognised as relevant firm capabilities: 
(1) managerial capability; (2) marketing capability; (3) technological capability; (4) R\&D capability; (5) innovation capability; and (6) human resources capability. Each capability has been investigated as a composition of the sensing, seizing and reconfiguring capabilities (see Figure 1).

Figure 1: Relevant firm capabilities according to the dynamic capabilities disaggregation

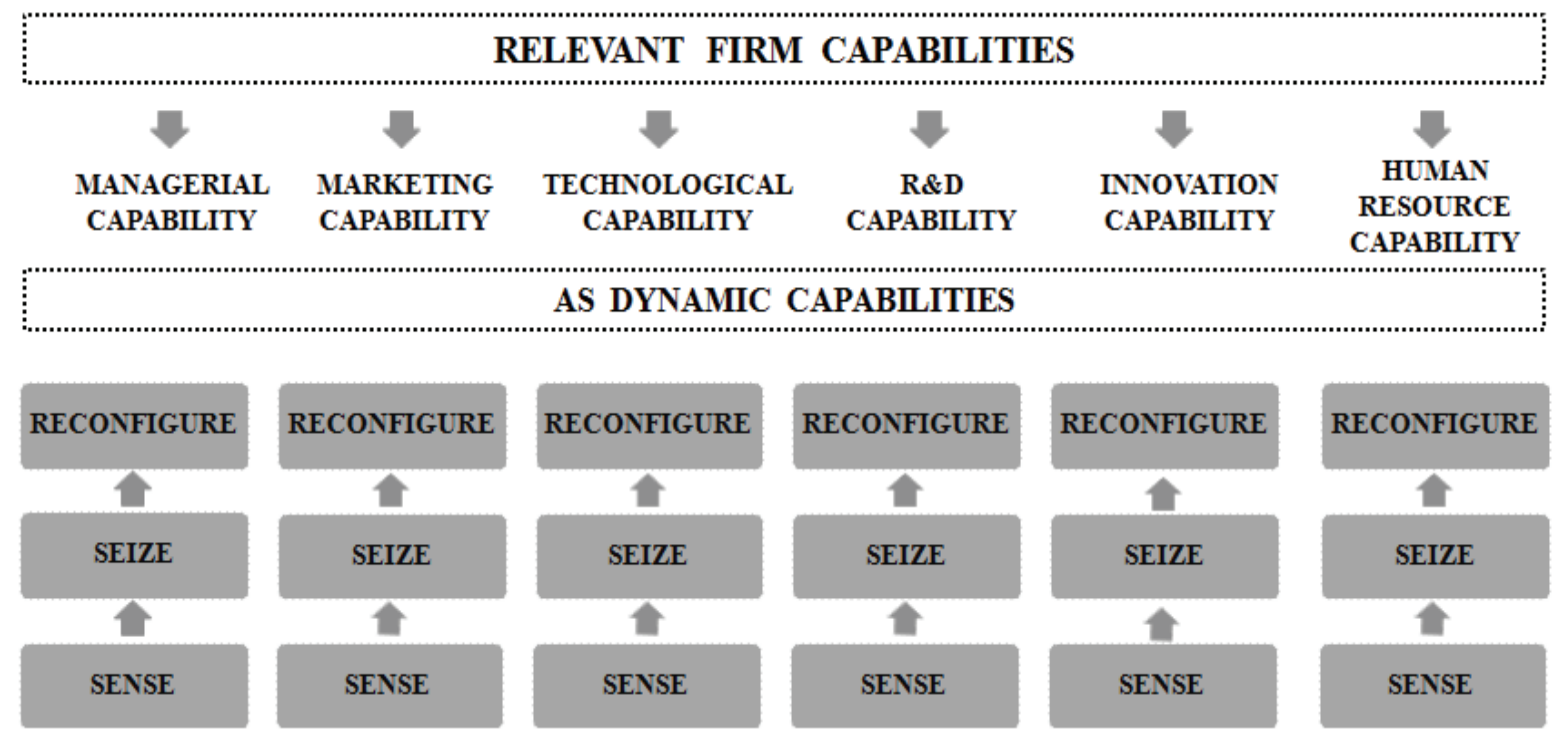

Managerial capability is a relevant, distinctive capability (Barney/Clark 2007). It may be seen as a key factor in creating and sustaining a competitive advantage. Managers' dominant role in developing dynamic capabilities is widely recognised (Rindova/Kotha 2001; Teece 2007:1335; Augier/Teece 2009:410), especially in reconfiguring the resource base (Ambrosini/Bowman 2009:41; Moliterno/Wiersema 2007:1081; Harreld et al. 2007). Rosenbloom's (2000) field-study of one technological firm confirms that the role of managers is a central element of developing dynamic capabilities. Research by Kor and Mahoney (2005) based on a study of 60 technological firms shows that managers play a crucial role in "rent-generating" dynamic capabilities. In addition, if a manager's perceptions of one particular situation are wrong this might trigger the wrong dynamic capabilities (Ambrosini/Bowman 2009; Adner/Helfat 2003). In such a case, the consequences could be fatal for a firm. Marketing capability is an "enduring source" of competitive advantage (Kor/Mahoney 2005:494). It helps create links and nurture relationships with customers (Song et al. 2005) and enables us to (out) compete by predicting customer preferences (Day 1994). Bruni and Verona (2009) presented the dynamic marketing capabilities concept. According to them, dynamic marketing capabilities enable firms to evolve and are therefore much more than an ordinary marketing capability. Namely, the central focus of dynamic marketing capability is developing, releasing and integrating market knowledge to successfully address changes in the environment. Technological capability is a core capability of every firm in today's dynamic environment, es- 
pecially technological firms operating in the IT industry. Considering the high technological turbulence, technological capabilities enable firms to develop, produce and use the "right" technology (Wind/Mahajan 1997 in Song et al. 2005).

Something similar can be acknowledged for R\&D capability. The ability to recognise and exploit knowledge is basically a result of $R \& D$ capability since that capability is a function of prior related knowledge (Cohen/Levinthal 1990). Accordingly, R\&D capability creates a firm-specific capability (Helfat 1997) and generates innovation potential. For technological firms, especially for firms in the IT industry, acquiring new knowledge and exploiting it through their resource base is a key factor of success (Verloop 2004). Moreover, collaborating and building partnerships, particularly strategic alliances, provide a useful platform to exchange, share and exploit knowledge between firms (Culpan 2008). In recent years, many firms in different industries have joined efforts to become more efficient in the global competition. Such partnerships can also be found in the IT industry, for instance the partnership between Microsoft and Lenovo or the partnership between Sony and Ericsson. Innovation capability has been recognised as a relevant capability, especially in a high velocity environment such as in the IT industry (Breznik/Lahovnik 2012). In fact, Birchall and Tovstiga (2005:4) state that innovation capability is probably the most important capability a firm can have. Their view is not new since Schumpeter (1934) already recognised the value of continuous innovation. To develop innovation capability through time, we must constantly search, scan, explore and implement new opportunities inside and outside the firm (Hii/Nelly 2000). The last firm capability relevant to our study of the deployment of dynamic capabilities is human resource capability. Human resources are recognised as one of the major sources of a competitive advantage (e.g. Barney/Clark 2007; Itami/Roehl 1987; Kamoche/Muller 1998; Lado/Wilson 1994). As the literature shows, human resource capability has become one of the most widely studied capabilities in the study of sources of competitive advantage (Newbert 2007).

The IT industry can be considered one of the most changing and dynamic environments in today's society. In the last few decades, IT has become a major facilitator of business activities and a vital driver of economic growth (Turban et al. 2006; Banuls/Salmeron 2008). In addition, the IT industry faces high demand for customisation and short product life cycles. Such dynamism of IT is forcing firms, especially IT firms, to constantly look beyond their boundaries and continually adapt their strategy to technological changes and opportunities. Obviously, the IT industry is a suitable context to test and validate our assumptions. Moreover, IT firms have a direct and/or indirect influence on other firms due to their nature and integration into other industries' environments. Our study focuses on small- and medium-sized enterprises (SME). SMEs have both advantages and disadvantages over their larger counterparts (Rothwell/Dodgson 1991). 
However, in both the USA and the EU SMEs represent the majority, namely 99\%, of all firms in the market (Jie et al. 2009:46; Eurostat). For the purpose of our study, we selected six key performing SMEs in the Slovenian IT industry. That industry is a very demanding and competitive environment, main-ly controlled by multinational firms such as Microsoft, SAP, Oracle and others. For most of the case-study firms' the golden era was the period up until the collapse of former Yugoslavia. After that, the case-study firms had to confront all the changes involved in the transition from socialism to a market economy. Since the case-study firms represent key performing Slovenian IT firms, they have evidently been more or less successful in facing and overcoming challenges in a highly demanding environment.

According to Eisenhardt (1989:545), there is no ideal number of cases, although a number between 4 and 10 seems to be the most ideal. Choosing the six casestudy firms seems to provide a corresponding sample for conducting a crosscase analysis, especially in the process of searching for and identifying common patterns and differences in the deployment of dynamic capabilities between the cases. The selection of the six firms was based on six indicators: (1) the casestudy firm is a SME; (2) the case-study firm has to have been active in the market for more than 10 years (the selected case-study firms should share the same historical issues, such as a transition process and globalisation effects); (3) the case-study firm has to be established in the home country, be locally owned (the selected case-study firms have an independent capital structure, they are not business units of foreign, global firms); (4) the business orientation and programmes of the case-study firms must be comparable (namely, firms in the IT industry can offer various products and services based on different strategic orientations; consequently, such diversity cannot support the comparison between cases); (5) the case-study firm has to be recognised as a relevant player in the market (their economic contribution and market share is relevant for the domestic market); and (6) the case-study firm has to be willing to participate.

We followed the steps and suggestions presented by Rouse and Daellenbach (1999) since their approach can be seen as giving guidance for studies of resource-based competitive advantage in a single industry. We chose a multiple case study approach as our research design (Yin 2009) and collected empirical data through in-depth interviews. In those interviews, we followed the questions that had been established on the basis of what had to be found out in each interview. The, questions, as interview guides, were distributed before the in-depth interviews with the key people responsible and directly concerned with the deployment of the firms' capabilities being studied. Given that our research focus was a group of SMEs, the target respondents were principally the general managers of the case-study firms. The interviews were informal and narrative in nature, tape-recorded (with permission) and later transcribed. The interviews lasted around 60-90 minutes. We conducted 13 interviews in total. Later, in the process 
of analysing the data, we also engaged in a number of telephone and Internet communications to resolve some specifics and dilemmas that were not clarified in the earlier phases of research. In order to minimise bias in qualitative research in general, we triangulated the data with other secondary sources on each case (data from financial and annual reports, a firm's internal documents, different publications, and data from public databases). It should be noted that one of the authors is an expert who has been working in the IT industry for several years already, and this has helped us to better understand the subject and, further, more profoundly conduct the research. Consistent with an inductive research approach, we moved back and forth among the literature. We used a coding process (Rubin/Rubin 2005; Saldana 2009) to code and categorise the data, as well as thematic networks (Stirling-Attride 2001). We used NVIVO9 as qualitative analysis software to maintain the linkage between the interview transcripts, direct quotes and data gathered from the coding process. Our analysis process as a content analysis consists of three phases (Yin 2009): (1) individual case analysis and report; (2) a cross-case analysis and report; and (3) cross-case conclusions and implications for theory and practice. In all phases of the analysis, both authors of this study were involved through individual findings and reports that were later checked and agreed on jointly. Since we mainly operated with diverse and unstructured data, we created a case-study database that allowed us to enhance the reliability of our study. We considered ethical dilemmas that can arise in qualitative research and consequently applied important ethical principles to our research.

\section{Results}

In this section, we present the main results of our study. At the beginning, we briefly introduce the case-study firms which we labelled Alpha, Beta, Delta, Gamma, Epsilon and Zeta, and their strategic orientations.

\subsection{Overview of the case-study firms}

Alpha was founded in the 1990s. It employs around 110 staff and had earnings of approximately $€ 11$ million in 2011. Alpha had the highest value for the return on equity and the second highest value for the return on assets and return on sales over the 2006-2010 period among the case-study firms. It also had the highest value for sales growth in the last 5 years (2006-2010) and the highest ratio of new employment (the number of employees rose by 44\% from 2006 to 2010). Beta was created in the 1970s as a spin-off of a university research institute. Today, Beta has around 55 employees and had net sales of around $€ 4$ million in 2011. Its overall financial performance is very good, especially the value of shareholders' funds to assets, which is around $80 \%$. Sales growth has been continuous at $2 \%$ per year. The number of employees went up by $17 \%$ from 2006 to 2010. Delta was established in 1999 as a spin-off of a large industrial firm. In 2011, the firm had 74 employees and net sales of around $€ 6$ million. 
Delta can be considered one of the more successful case-study firms. Its value for the return on assets and the ratio between total revenues and total expenses are the highest. In the last 5 years (2006-2010), Delta's sales growth decreased by $5 \%$. However, on the other side, Delta increased the number of its employees by 70\% during 2006-2010 and achieved an EBIT of over $€ 1$ million in 2011 . Delta also has the highest salary income and value added per employee among the case-study firms. Namely, value added per employee is almost twice as high as the values achieved by Gamma and Epsilon for the 2006-2010 period. Gamma was founded in the 1990s. In 2011, the firm had around 70 employees and earnings of around $€ 7$ million. Gamma is one of the case-study firms that had difficulties achieving a good performance. The average of value added per employee and the average of salary income for the 2006-2010 period are the lowest among the case-study firms and below the industry average. Sales growth was negative for the 2006-2010 period. Specifically, in this period the decrease was around $11 \%$, although the biggest sales fall was registered between 2008 and 2010 when the sales growth was more than $-20 \%$. In addition, the number of employees was reduced from 90 to 70 . Epsilon was founded in the 1980s, has around 60 employees and had net sales of around $€ 4.5$ million in 2011. The overall performance is similar to that of Gamma. Most of the studied financial and non-financial indicators are below the average values of the case-study firms. Epsilon's employee growth and sales growth were negative for the 20062010 period. The management board was shocked by the results; namely, between 2008 and 2009 sales dropped by more than 30\% and EBIT by $70 \%$. Zeta was established more than 15 years ago. Approximately nine years ago, the firm was taken over by a large state-owned firm. Strong financial support from the parent company has helped Zeta achieve a superior performance, especially in the period after the takeover. Zeta recruited 55 employees in the 2006-2011 period and today has 140 employees. Zeta's net sales amounted to $€ 25$ million in 2011. The economic crisis has had a negative impact on Zeta's performance, especially in 2010 when the firm had around $20 \%$ lower earnings than the year before and a negative EBIT.

The case-study firms recognise the IT industry as dynamic and highly dependent on technological development. Naturally, such conditions require constant and quick adaptions to the changing environment. Consequently, this can be achieved solely by continuously sensing, seizing opportunities inside and outside firm boundaries and, further, exploiting these opportunities through a recombination and reconfiguration of the resource base. According to the high level of dynamism in IT in general, commitment to changes is incorporated in daily practices and making adjustments to accept novelties and risks is simply 'a must' in all the case-study firms. In addition, intuition plays an important part in their decision-making process. When considering the strategic orientation of the case-study firms, differentiation is a type of strategy most of those firms follow. Porter (1985) states that a firm which can achieve and sustain differentiation will 
be an above-average performer in its industry. Three of the six case-study firms, i.e. Alpha, Beta and Zeta, are differentiators. Their main focus is on constantly trying to find ways of differentiating themselves from their rivals. The fourth case-study firm, Delta, seeks to differentiate itself in its target segment. This strategy orientation is known as a differentiation focus. The last two case-study firms, Gamma and Epsilon, try to engage themselves in all generic strategies, yet they fail to achieve any of them. Accordingly, their strategy can be viewed as a 'stuck in the middle' strategy.

\subsection{Overview of the development of dynamic capabilities in the case-study firms}

Figure 2 provides an overview of the deployment of all six relevant capabilities that were studied as dynamic capabilities in each case-study firm. In line with our conceptual model, each capability was disaggregated into sensing, seizing and reconfiguring capabilities. These three capabilities were further evaluated through their level of deployment. We defined three levels of deployment: weak, moderate and strong. The evaluation of each capability was made possible after we conducted the cross-case analysis. By comparing the results and reports of each case-study firm, we were able to distinguish the levels of deployment of capabilities. As Figure 2 shows, some capabilities are evaluated as weak, e.g. human resource capability. Human resource capability is in most cases at the strongest level of deployment, although in two cases its level is weak. When we compared the findings, we found that a strong evaluation of human resource capability is linked with established practices in the human resource area, e.g. applied mentorships, high job satisfaction, an effective reward system, time for developing new ideas etc. On the contrary, a weak evaluation is linked to 'bad' practices, e.g. no systematic mentorships, low job satisfaction, an unattractive reward system, a lack of creativity, the unexpected resignation of key employees etc.

In sum, all six case-study firms develop relevant capabilities as dynamic capabilities. However, the levels of deployment of each capability vary among the case-study firms. The results show that Alpha and Beta have the strongest level of deployment with regard to all capabilities. Delta has high deployment scores for each capability, except the managerial capability. Zeta is one of the more successful firms regarding the development of its dynamic capabilities, although its marketing and human resource capabilities are less developed. The deployment levels of dynamic capabilities of the next two case-study firms, Gamma and Epsilon, are the weakest. Gamma has some capabilities at the strongest level and some at the moderate level of deployment, but its level of human resource capability is at the lowest level. The last firm, Epsilon, has the lowest scores of dynamic capabilities deployment among the case-study firms, particularly in re- 
configuring its capability with managerial, marketing and human resource capabilities.

Figure 2: An overview of the deployment of dynamic capabilities in the casestudy firms

\begin{tabular}{|c|c|c|c|c|c|c|}
\hline \multirow[b]{2}{*}{ Capabilities } & \multicolumn{6}{|c|}{ Case-study firms } \\
\hline & ALPHA & BETA & GAINLA & DELTA & EPSILON & ZETA \\
\hline \multicolumn{7}{|l|}{ Managerial capability } \\
\hline (1) sensing & strong & strong & moderate & strong & moderate & strong \\
\hline (2) seizing & strong & strong & moderate & strong & moderate & strong \\
\hline (3) reconfiguring & strong & strong & strong & strong & WEAK & moderate \\
\hline \multicolumn{7}{|l|}{ Marketing capability } \\
\hline (1) sensing & strong & strong & strong & strong & strong & strong \\
\hline (2) seizing & strong & strong & strong & strong & moderate & strong \\
\hline (3) reconfiguring & strong & strong & moderate & moderate & WEAK & moderate \\
\hline \multicolumn{7}{|c|}{ Technological capability } \\
\hline (1) sensing & strong & strong & strong & strong & strong & strong \\
\hline (2) seizing & strong & strong & strong & strong & strong & strong \\
\hline (3) reconfiguring & strong & strong & moderate & strong & moderate & strong \\
\hline \multicolumn{7}{|l|}{ R\&D capability } \\
\hline (1) sensing & strong & strong & strong & strong & strong & strong \\
\hline (2) seizing & strong & strong & strong & strong & strong & strong \\
\hline (3) reconfiguring & strong & strong & moderate & strong & moderate & strong \\
\hline \multicolumn{7}{|l|}{ Innovation capability } \\
\hline (1) sensing & strong & strong & strong & strong & strong & strong \\
\hline (2) seizing & strong & strong & strong & strong & strong & strong \\
\hline (3) reconfiguring & strong & strong & moderate & strong & moderate & strong \\
\hline \multicolumn{7}{|c|}{ Human resource capability } \\
\hline (1) sensing & strong & strong & strong & strong & strong & strong \\
\hline (2) seizing & strong & strong & moderate & strong & moderate & strong \\
\hline (3) reconfiguring & strong & strong & WEAK & strong & WEAK & moderate \\
\hline
\end{tabular}

For a better understanding of manifestations of the sensing, seizing and reconfiguring capabilities, we present an overview of the practices that underpin dynamic capabilities in the case study-firm Beta, all of whose dynamic capabilities are at the strongest level (see Appendix 1).

Alpha, Beta, Delta and Zeta very successfully deploy managerial capability as a dynamic capability (see Figure 3). All three of the sensing, seizing and reconfiguring capabilities are at the strongest level. Gamma is less successful due to the moderate level of its deployment of managerial capability in line with the sensing and seizing capabilities. However, it has a strong level of deployment of its reconfiguring capability. The main reason for this strong reconfiguring capability is the firm's past reorganisation process and changes at the top management level. However, the firm generally did not achieve the results expected from the managerial capability. A deeper investigation of the managerial capability shows that the reasons for its lower scores lie in its unsuccessful deployment of the sensing and seizing capabilities. Similar results were found for Epsilon. Moreo- 
ver, the firm is even less successful according to its weak reconfiguring capability. Regarding managerial capability, Epsilon was able to sense and seize opportunities, yet it was unable to reconfigure its resource base in line with the recognised opportunities. Zeta has achieved a superior performance and outstanding firm growth in recent years. The main reason for the firm being able to outperform its competitors lies in the radical business process reengineering the firm successfully adopted. The foundations of Zeta's success can be linked to the strong deployment of managerial capability. However, there were some big changes in the top management team (two top-level managers resigned) in 2010 that resulted in a lower performance in 2010 and 2011. Given these circumstances, Zeta's level of reconfiguring capability cannot be evaluated as strong but merely as moderate.

Figure 3: Levels of deployment of managerial capability in the case-study firms

Managerial capability

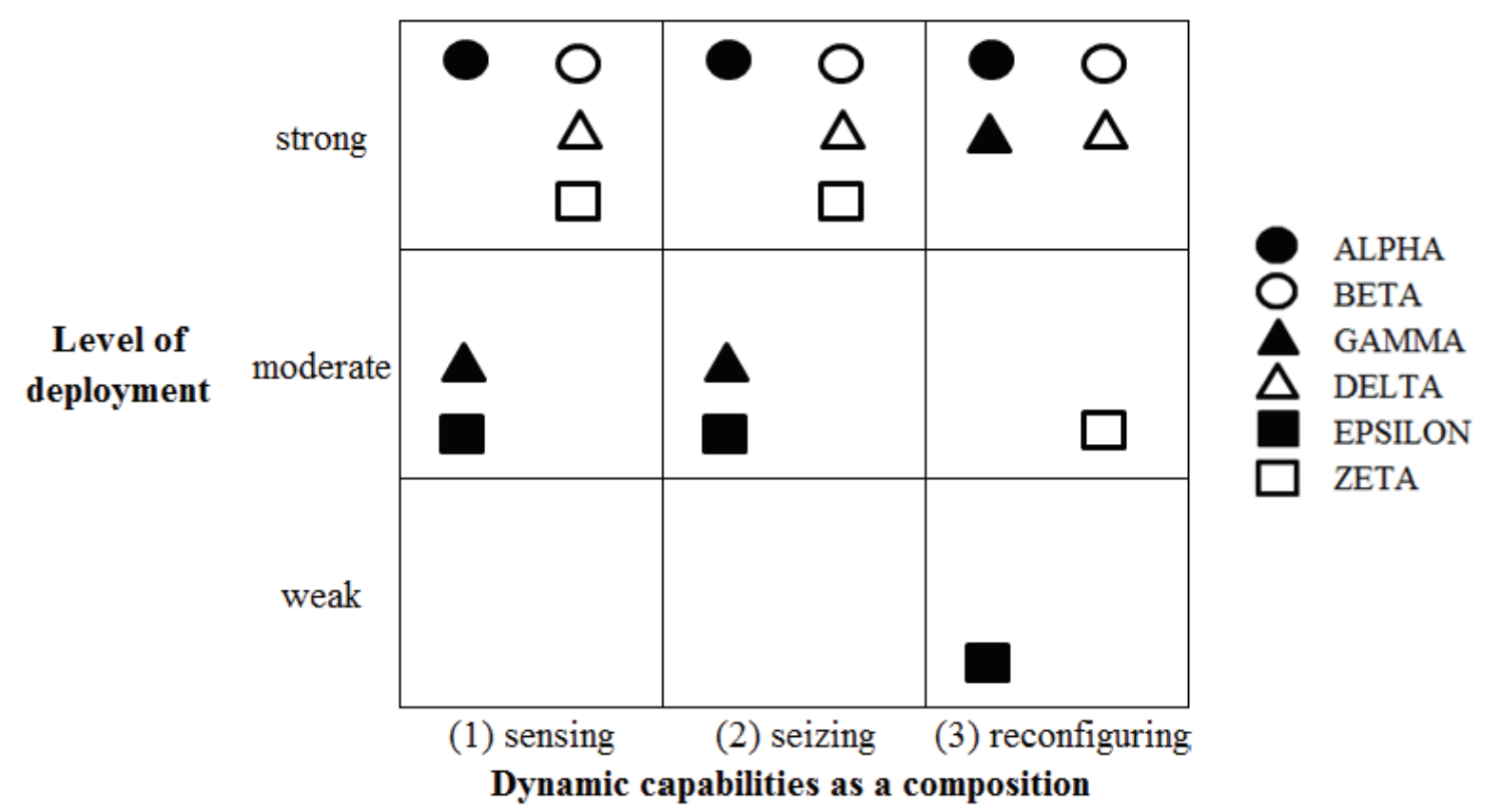

"We don't have any company cars because that creates a hierarchy." (Sales manager, Alpha)

Among all case-study firms the sensing capability within marketing capability is at the strongest level (see Figure 4). The same evaluation can be made for the seizing capability, except for Epsilon which has a moderate level of such capability. In terms of their reconfiguring capability, only Alpha and Beta are successful since all the others have difficulties deploying their reconfiguring capability. The reasons are as follows. Gamma recognises the need to make changes in its marketing process by reconfiguring its resource base; however, the reconfiguration process was only partly completed. On the other side, Delta successfully completed the reconfiguration process related to its marketing capability. Yet the firm was unable to sustain a strong level of deployment of its marketing 
capability. Namely, during and after its reconfiguration process some new opportunities were recognised but they have not been exploited. This consequently pushes its reconfiguring capability back to a moderate level. Zeta successfully managed to enter foreign markets, yet its activities were not as thoroughly accomplished as planned. As a result, the lower performance was a result of negative sales growth. The last case-study firm, Epsilon, has the lowest scores when it comes to evaluating its marketing capability development. The main reason is the unsuccessful adaption of its marketing capability to a changing environment.

Figure 4: Levels of deployment of marketing capability in the case-study firms

Marketing capability

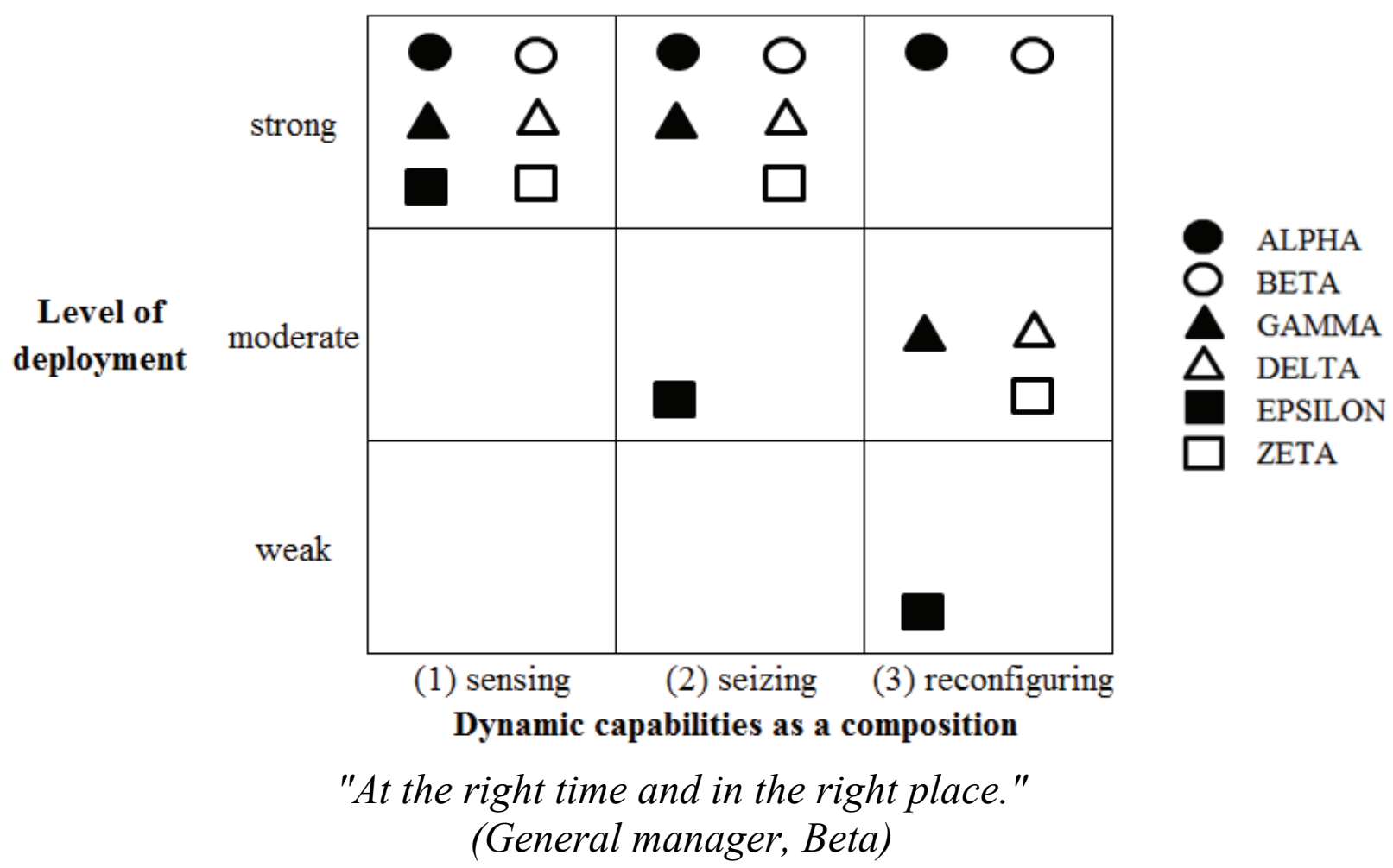

The sensing and seizing technological, $R \& D$ and innovation capabilities are strongly developed in all case-study firms (see Figure 5). Such results were expected since technology and the ability to adapt to it play a crucial role in sustaining a competitive position for IT firms in general. Moreover, for firms in the IT industry the question of survival largely depends on constantly searching for, exploring and adapting to technological changes. Despite this, some case-study firms, i.e. Gamma and Epsilon, have not been as successful as the others in developing their technological capability, especially the reconfiguring capability. In looking for reasons for this less developed technological capability, we recognised that both firms have a similar business model/assortment and compete for the same market/customers. Further, we identified that both firms try to outcompete each other through price/cost cannibalism. 
Figure 5: Levels of deployment of technological, $R \& D$ and innovation capabilities in the case-study firms

Technological, R\&D and innovation capabilities

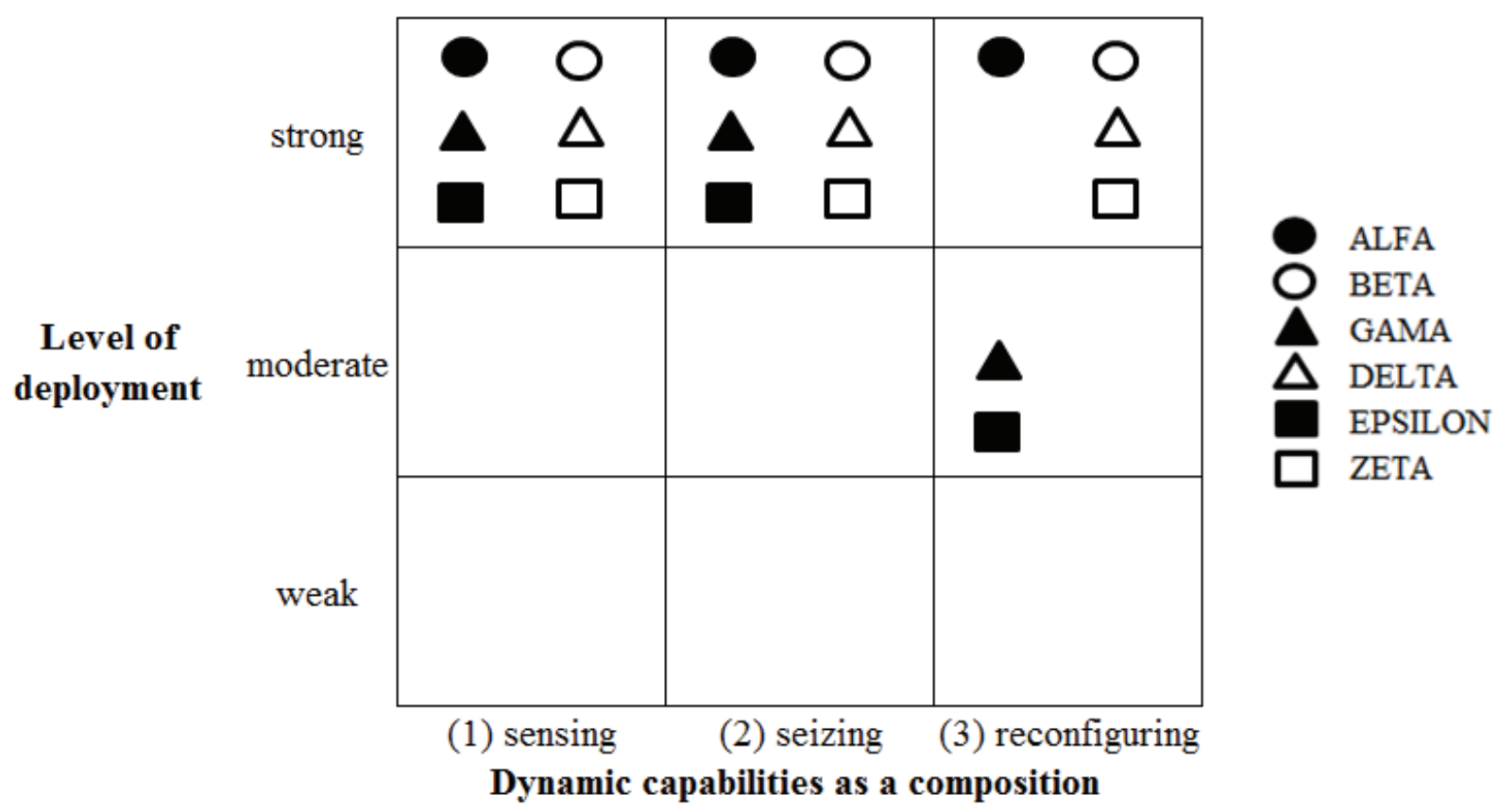

"If a competitor shows you the solution but you don't know what to do with it, what's the point?"

(General manager, Gamma)

Human resource capability is the strongest in Alpha, Beta and Delta (see Figure 6). Zeta is successful according to its sensing and seizing capabilities, yet its reconfiguring capability is moderate. The results show that the activities and goals planned in the human resource strategy have not been accomplished yet. The last two firms in the sample, i.e. Gamma and Epsilon, have difficulties deploying and developing their human resource capability. Their sensing capability is indeed strong but their seizing capability is moderate and reconfiguring capability is weak. Both firms are able to sense opportunities in their human resource capability, although their ability to develop, integrate and recombine their resource base according to the human resource strategy is undernourished and unfocused. 
Figure 6: Levels of deployment of human resource capability in the case-study firms

\section{Human resource capability}

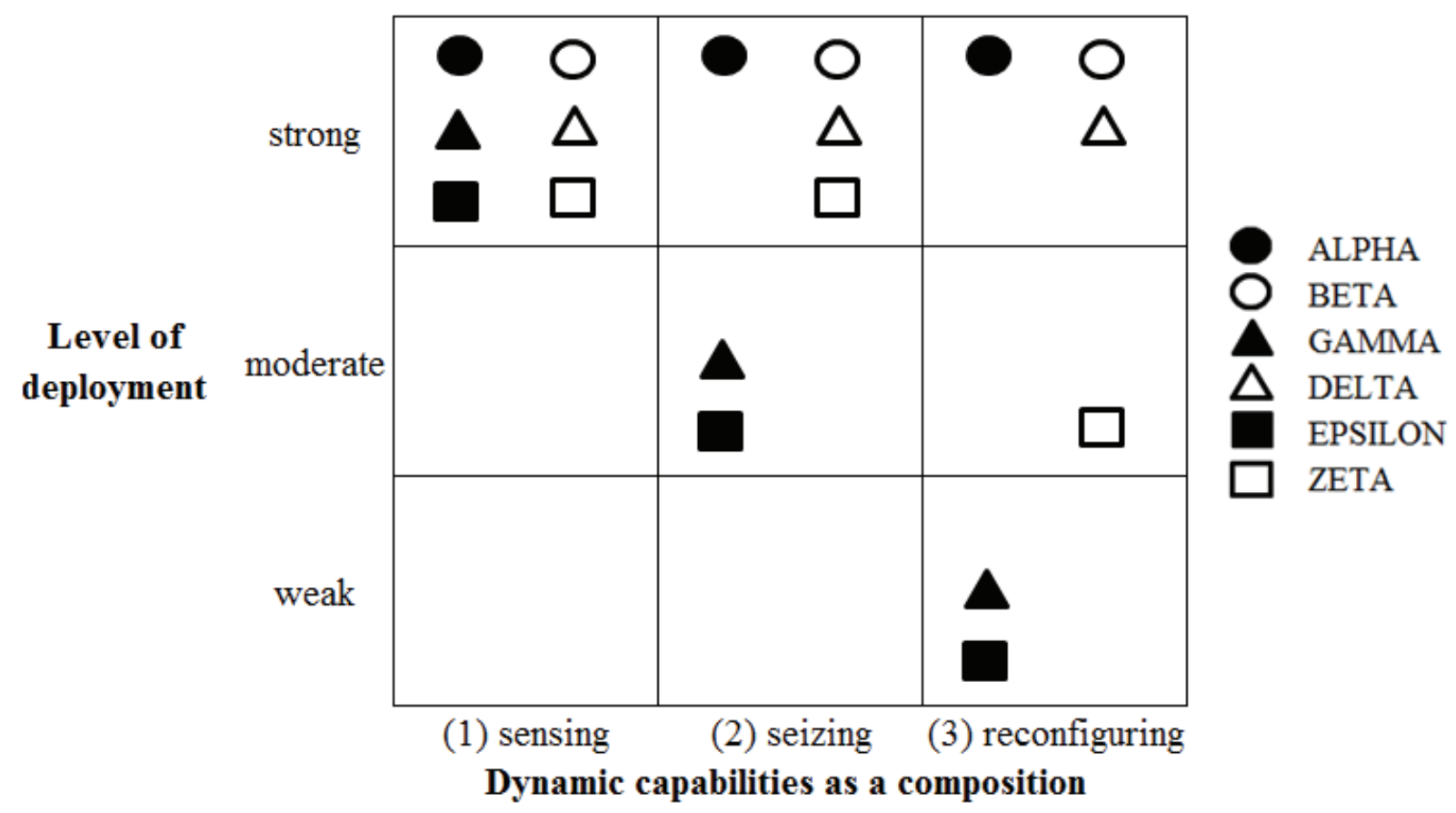

"When we recruit, we don't recruit the best on the market but what is the best for our firm."

(General manager, Delta)

As Figure 7 shows, in each case study firm we studied six relevant capabilities that we had earlier disaggregated into three capabilities: sensing, seizing and reconfiguring. First, we evaluated the levels of deployment of 18 capabilities (six relevant firm capabilities (managerial, marketing, technological, R\&D, innovation and human resource) multiplied by the three classes of dynamic capabilities (sensing, seizing and reconfiguring) in each firm. Second, we analysed and compared the deployment levels with the performance of each case-study firm (Appendix 3 describes the case-study firms according to their outstanding results - positive and negative). Third, we conducted a cross-case analysis of the levels of deployment and firm performance. The results allowed us to distinguish low performing and high performing firms and then to link the overall performance results with each case-study firm's deployment of dynamic capabilities. For the overall performance, we considered a combination of selected financial and nonfinancial indicators and management self-evaluations. Each financial and/or non-financial indicator was deeply investigated and compared with the others. Moreover, we considered the specifics of the IT industry that may influence the relationship between costs and revenues (for instance, payments in the next fiscal year, long sales cycles, financing R\&D activities etc). Evidently, as Figure 10 shows, firms that are less successful in developing their dynamic capabilities 
have an overall weak performance, and vice versa. For instance, the firms Alpha and Beta, which are good performers, have all their capabilities at the highest level. On the other side Epsilon, which we had recognised as a bad performer, has difficulties deploying its dynamic capabilities. Namely, the level of its deployment of dynamic capabilities is moderate. Moreover, some capabilities, especially reconfiguring ones, are even not developed at all.

Figure 7: Relationship between levels of deployment of dynamic capabilities and firm performance

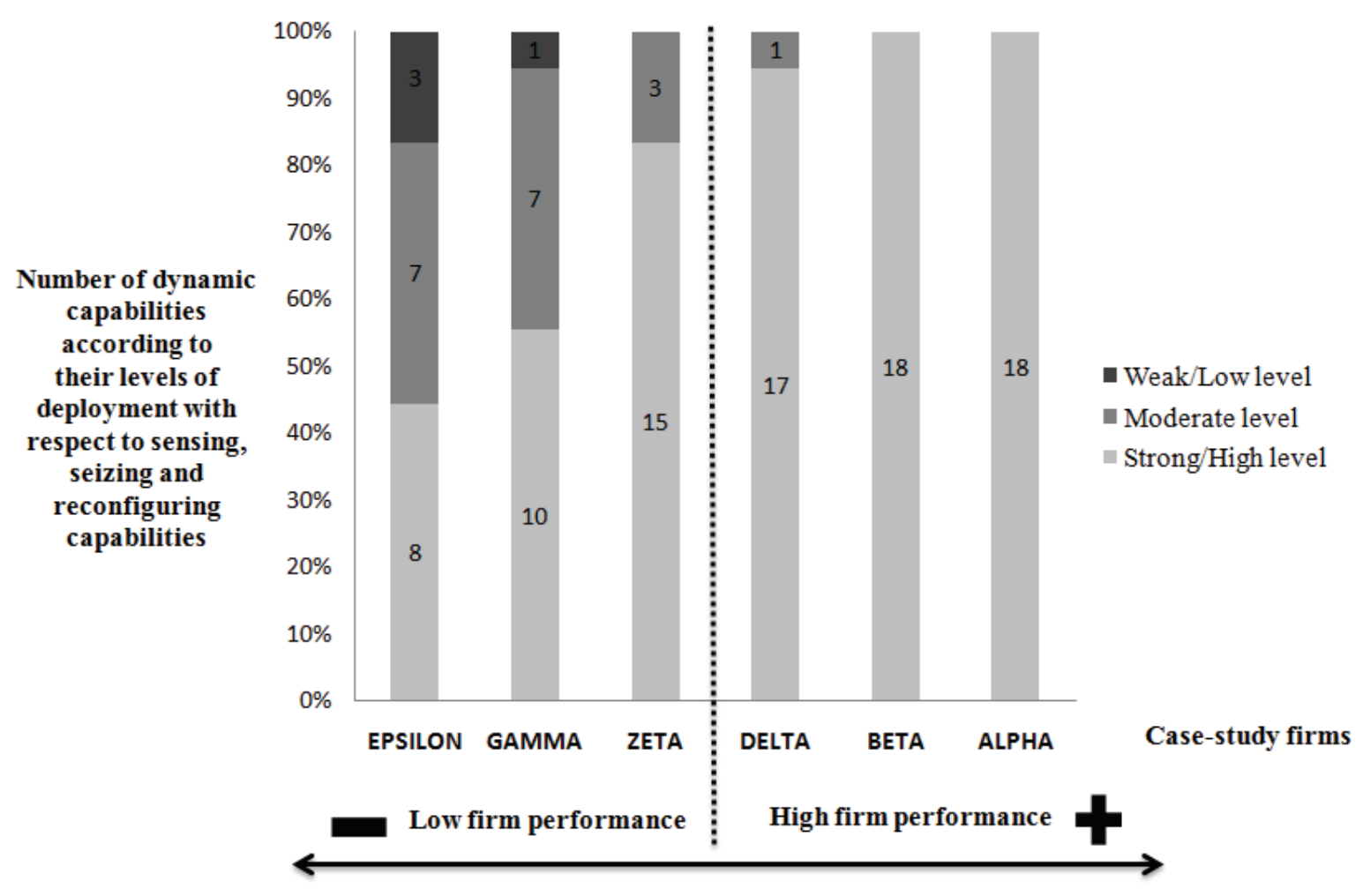

\section{Discussion and implications}

This research's main purpose was to recognise dynamic capabilities as a source of competitive advantage in the high velocity environment of the IT industry. In addition, we sought a deeper understanding of dynamic capabilities by exploring their deployment and development through their three components, i.e. sensing, seizing and reconfiguring capabilities. The cross-case analysis revealed that those firms with relatively strong dynamic capabilities in all three capabilities, i.e. sensing, seizing and reconfiguring, have an overall better performance. The results also showed that firms more strongly committed to deploying dynamic capabilities are more successful and hold the potential for a sustained competitive advantage. On the contrary, firms finding it difficult to deploy dynamic capabilities have a weaker performance. Moreover, a competitive advantage in these firms was not recognised. Zott (2003) and Zahra, Sapienza and Davidsson (2006) contend that dynamic capabilities do not have a direct impact on firm 
performance but have an indirect impact by modifying a firm's bundle of resources. Eisenhardt and Martin (2000:1106) maintain that "dynamic capabilities are necessary, but not sufficient conditions for competitive advantage". We suggest that dynamic capabilities directly impact on firm performance and competitive advantage since their core purpose is indeed to create and sustain a competitive advantage and thus the related firm performance (see Figure 8). However, the following has to be acknowledged.

Figure 8: Dynamic capabilities as a source of competitive advantage and firm performance

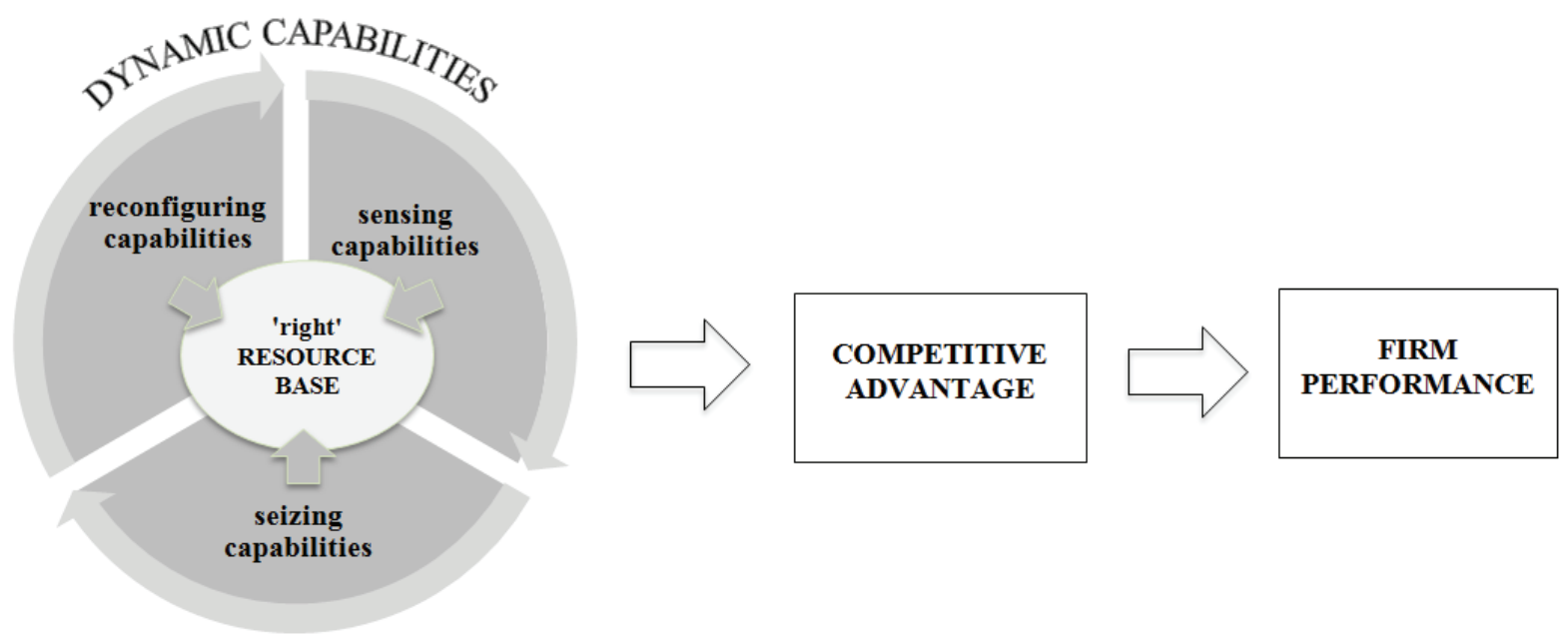

First, dynamic capabilities operate on a resource base. Accordingly, without the 'right' resource base the mere deployment of dynamic capabilities cannot be successful and, vice versa, simply possessing and developing the 'right' resource base but without exploiting and adapting it in line with dynamic capabilities will not be enough to sustain a competitive advantage. One firm in our study ignored the fact that resources, regardless of their value, rareness or inimitability, are not static and that they have to be continuously developed and adapted to the changing environment. The management team of that firm had lost its 'competitive value'. By losing competitive value we mean not being able to adapt the firm's business model to environmental demands, and hence that management team became a core rigidity (Leonard-Barton 1992). Second, the literature indicates that dynamic capabilities can lead to competitive advantage, competitive parity or even to competitive disadvantage. We suggest that the impact of dynamic capabilities on competitive advantage and firm performance should be viewed from a positive perspective. We agree with Zott (2003:120) who recognises that "dynamic capabilities are more than a simple addition to the resource-based view since they manipulate the resources and capabilities that directly engender rents", and with Teece (2009:7) who points out that "dynamic capabilities have no doubt been relevant to achieving competitive advantage". Moreover, dynamic capabilities can be viewed as a conductor that orchestrates resources and capabilities in the resource base (Katkalo et al. 2010). 
As seen in Figure 8, there is a clear casual relationship between dynamic capabilities and firm performance. The findings show that firms with a stronger commitment to deploying dynamic capabilities are more successful and hold the potential for a sustained competitive advantage. As theory suggests, the DCV allows firms to respond to changes by altering their resource base. The more successful firms are with that adaption, the better their performance. We argue that renewing the resource base in line with the DCV has a positive impact on firm performance.

Since our research relies on a qualitative analysis, we carefully selected the casestudy firms. Industry (the IT industry) was a necessary control variable, then firm size (the SMEs') and firms' specifics as a powerful explanatory variable regarding firm performance (Wernerfelt/Montgomery 1988) and, finally, our study is based on six representative firms in the IT industry. The case-study firms operate in the IT industry whose environment has been exposed to rapid technological change and aggressive international competition. The findings show that the case-study firms do develop dynamic capabilities more or less successfully. From this point of view, they are all successful in terms of being able to survive in such a dynamic sector, especially in the extreme market conditions. Namely, industry analysis shows that the survival rate is quite low in the Slovenian IT market. In our study, performance is a dependent variable. Being able to renew the resource base does not necessarily involve large inputs, for instance, monitoring the environment can be a low-cost activity. We can accordingly suggest that a lack of financial resources cannot be an obstacle to the deployment of dynamic capabilities. On the other side, a firm can hire an expert simply because it can afford to do so (good financial performance), but if that expert's potential does not develop in line with the DCV the costs (e.g. labour costs) would exceed the benefits (e.g. unexploited knowledge/potential).

Our research findings demonstrate that all relevant dynamic capabilities have to be deployed and developed. Disregarding the development of one of them can negatively impact the other dynamic capabilities since they are interdependent and interwoven. Recognising a marketing opportunity and establishing a strategy for developing a marketing capability will not be successful if other dynamic capabilities are not simultaneously adapted and exploited. Namely, it can easily happen that a product is developed for which the market is not yet prepared. We found such an example in one case-study firm which had introduced an innovative product that was too advanced for the market at that point in time. A major consequence for this case-study firm was the negative impact on its firm performance. In addition, non-economic effects of this 'bad decision' subsequently led to a lower level of creativity and motivation for the innovation process. Accordingly, our research findings are in line with the argument of Zahra, Sapienza and Davidsson (2006) who point out that developing dynamic capabilities under the wrong cause-effect assumptions can damage a firm's performance. 
Figure 9: The relationship between dynamic capabilities - the central role of innovation capability

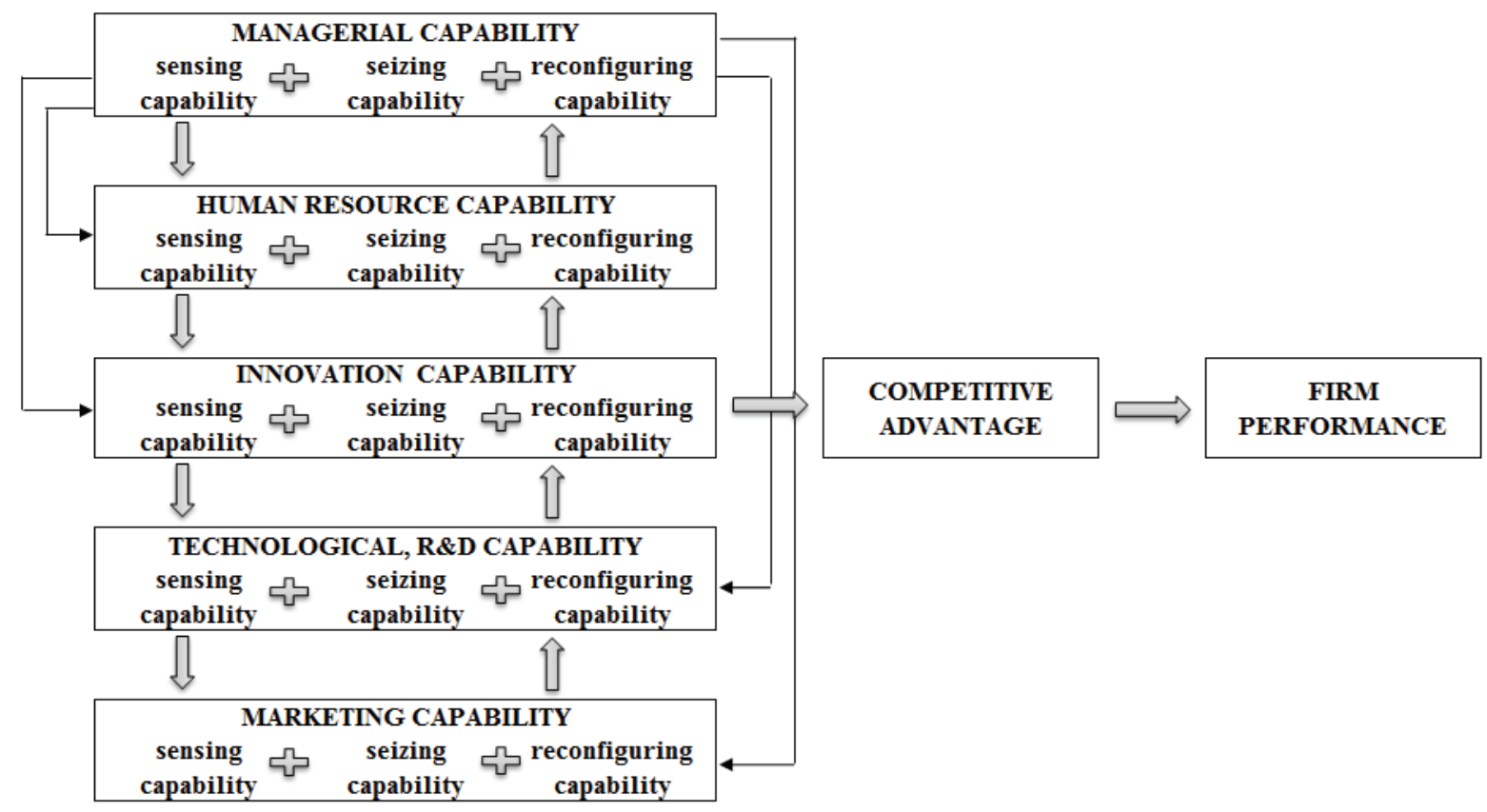

Our results show that managerial capability and human resource capability are capabilities whose deployment and development seem to be the most difficult and complex. Further, both capabilities deal with people, i.e. human resources, that play a central role in the development of dynamic capabilities. In fact, human resources can be seen as an absolute resource, especially in the IT industry where employees and their knowledge, mostly embedded as tacit knowledge, provide a basis for creating and sustaining a competitive advantage. Some casestudy firms were able to recognise and exploit their human capital better and more successfully than other firms in the sample. Evidently, these firms are overall more successful. We noticed that managers and their capabilities have a strong impact on stimulating or impeding the deployment and development of dynamic capabilities and thus the related resource base. We recognise two dominant dynamic capabilities, although all of the studied dynamic capabilities are relevant and must be simultaneously developed. As the first dominant or key dynamic capability we propose innovation capability. Innovation capability can be seen as a strategic power and a radar for firms in the IT industry. As the second dynamic capability we recognise managerial capability, which is both an engine and a driving wheel of IT firms. In Figure 9 we present a model of the relationships of dynamic capabilities in the IT industry. As a core dynamic capability we depict innovation capability that is interdependent and interwoven with other dynamic capabilities. Their relationships are clearly represented by arrows in Figure 9. In addition, since managerial capability is an engine that pushes the deployment and development of other dynamic capabilities, and also a driving wheel that directs and manipulates other dynamic capabilities, we highlight that 
relationship with extra arrows deriving from managerial capability to other dynamic capabilities.

\subsection{Implications for scholars}

From a theoretical point of view, our study contributes to the literature of dynamic capabilities field by showing that a framework of disaggregating dynamic capabilities into three classes can be empirically developed and tested. We believe our work makes some important contributions to the current debate about the DCV. First, we analysed the empirical counterparts of Teece's (2007) conceptual typology of dynamic capabilities with a view towards empirical operationalisation. We showed how the deployment and development of capabilities can be explored through sensing, seizing and reconfiguring capabilities. Taking such a perspective enabled us to better understanding the logic behind the DCV and distinguish it from previous approaches. Second, our study points out how important it is to understand that simply possessing and developing the 'right' resource base but without exploiting and adapting it in line with dynamic capabilities will not be enough to sustain a competitive advantage. Third, our paper focuses on dynamic capabilities through detailed cross-case studies of firms operating in a highly demanding market. Using the qualitative analysis approach enabled us to provide insights into manifestations of the deployment of dynamic capabilities, and that could form the basis for developing managerial prescriptions. In Appendix 3, we present a comparison of selected relevant empirical findings of dynamic capability research studies with our relevant findings. We believe that this overview represents a contribution and can be seen as a template for scholars to move toward the consolidation of the main findings from previous research in a more focused way and, of course, to try to develop a contingency approach to dynamic capabilities.

\subsection{Implications for managers}

Managers need a theoretical understanding of their firm's survival and growth. As the firm grows, it has more resources to manage and orchestrate. In addition, resources and capabilities become ever more complex and interwoven. To be able to convincingly demonstrate the theoretical understanding through practical implications, managers have to gain insights into good practices, usually gathered by fine-grained case studies. In this paper, we proposed that the dynamic capabilities framework can help managers recognise and exploit opportunities inside and outside the firm's environment. As we can learn from the case studies, everything does change and it is solely those firms that are able to tackle the ongoing changes that will be able to survive. The basic idea of the DCV is to constantly search for, scan and exploit new opportunities inside and outside firm boundaries. Opportunities are all around us, yet competitors may not recognise an opportunity or perhaps calibrate it differently. As we suggest, managers must be open-minded, realise opportunities and be willing to take risks. However, 
they still have to be careful because a firm that is excellent at making the wrong things will fail.

Managers also need to understand that the capability to sense opportunities is not equally distributed amongst firms and that capabilities to seize and then transform opportunities also depend on managers' and employees' perspectives and their abilities to use and exploit knowledge. Sometimes an opportunity can be easily sensed, recognised and implemented, but in other cases it might require major steps in the transformation process. Our research offers insights into the good practices that underpin dynamic capabilities in a top performing case-study firm. This overview of good practices can provide a suitable starting point for managers to benchmark their practices and to think about how to use them in their daily practice. It can help them understand how they can develop uniqueness and competitive advantage in highly competitive environments such as the IT sector. The intention of identifying relevant capabilities was to emphasise that all of the capabilities are relevant and firms need to simultaneously deploy and develop all of the capabilities as dynamic capabilities. Moreover, dynamic capabilities operate on a resource base, they are not a stand-alone factor and they have to be orchestrated. The resource base is a bundle of heterogeneous resources that each firm deploys and develops individually. It is important to acknowledge that what is relevant for one firm is not necessarily important for another. For instance, the best candidate in the market is not necessarily the best candidate for our firm, although it may be the best candidate for our competitor.

Our research revealed that firms with a clear vision and differentiation as a type of selected orientation are generally more successful since they are trying to find ways to differentiate themselves from their rivals. However, simply picking differentiation as a winning strategy is not enough. Every activity, process and task has to be in line with the chosen strategy, everything has to be orchestrated. It is very important for managers to realise that intangible resources, such as the knowledge and skills incorporated in human and managerial capability, have risen up to the point where they overshadow economies of scale. Some casestudy firms were able to recognise and exploit their human capital better and more successfully than other firms in the sample. As suggested, those firms are overall more successful. Our research findings demonstrate that we have to deploy and develop all relevant dynamic capabilities. Disregarding the development of one of them can negatively impact on the other dynamic capabilities since they are interdependent and interwoven. Recognising a marketing opportunity and establishing a strategy for developing a marketing capability will not be successful if we do not simultaneously adapt and exploit other dynamic capabilities. Namely, it can easily happen that we develop a product for which the market is not yet prepared. We found such an example in one case-study firm where the introduction of an innovative product was too advanced for the market at that point in time. A major consequence for this firm was a negative impact 
on its overall performance. In addition, non-economic effects of this 'bad decision' subsequently led to a lower level of creativity and motivation for the innovation process. We noticed that managers and their capabilities have a strong influence on stimulating or impeding the deployment and development of dynamic capabilities and thus the related resource base. The management team of that firm had lost its 'competitive value'. By losing competitive value we mean not being able to adapt the firm's business model to environmental demands and hence that management team became a core rigidity (Leonard-Barton 1992).

\section{Limitations and future research opportunities}

This paper contributes to the dynamic capabilities literature by providing empirical support to better understand the embedded nature of dynamic capabilities. The DCV currently offers many challenges for scholars. Still, a few potential limitations of our study have to be addressed. This is an explorative, qualitative study based on a sample of six representative firms in the IT industry. The findings are not intended to be generalised to a population or other contexts but to offer empirical insights that extend the theoretical and empirical framework of the dynamic capabilities approach. Some scholars are convinced that the selection of cases can always be criticised, even if based on a theoretical background. Our study opens avenues for future research, especially to tackle the mentioned limitations and, further, to overcome the challenges created by the field of dynamic capabilities.

Follow-up studies could focus on a deeper investigation of each dynamic capability, especially the paths and positions affecting the development of dynamic capabilities, which exploit capabilities and/or resources in a firm's resource base. A more detailed insight into manifestations that underpin dynamic capabilities would also be valuable. Our sample is based on six representative firms in the IT industry. As an extension of this study, it would be useful for the sample to comprise a greater number and wider variety of units based on different selection criteria. Longitudinal research would also be valuable since the results of deploying and developing dynamic capabilities are usually not visible in the short term. The same or a similar study could be conducted in other industries, perhaps in a more dynamic, technology-based industry such as the biotechnology industry or a more stable environment like the footwear industry. As a next step, a cross-industry analysis could reveal commonalities and diversities in deploying dynamic capabilities across industries, while an international comparison would also be possible. Future studies exploring the dynamic capabilities field should involve other qualitative approaches such as focus groups or observation methods. In addition, a research framework that enables quantitative empirical testing would also be a step forward. 


\section{Conclusion}

This paper's main objective was to indicate that firms which renew their resource base in line with the DCV can generate and sustain a competitive advantage. The results show that firms which deploy dynamic capabilities hold the potential for a sustained competitive advantage. In addition, we found that firms with a stronger commitment to deploying dynamic capabilities are more successful, and vice versa. The results suggest that firms need to continuously deploy all relevant dynamic capabilities. Ignoring the deployment of a single dynamic capability can negatively affect the deployment of other dynamic capabilities since they are correlated and interwoven. Moreover, dynamic capabilities are not a stand-alone target; they are necessary but not sufficient conditions for a competitive advantage. The deployment of dynamic capabilities cannot be successful without 'the right' resource base and, inversely, exploitation of 'the right' resource base outside of the context of dynamic capabilities cannot bring the expected results.

Our study reveals that two dynamic capabilities in the case-study firms are more dominant in the process of creating and sustaining a competitive advantage, although all of the studied dynamic capabilities are relevant and must be developed simultaneously. As the first dominant or key dynamic capability, we propose innovation capability that can be seen as a strategic power of IT firms. As the second dominant dynamic capability, we recognise managerial capability, which is both an engine and a driving wheel of IT firms. Our results also show that managerial capability and human resource capability are capabilities that are most difficult and complex to deploy and develop. In addition, both capabilities deal with people, i.e. human resources, that have a central role in the development of dynamic capabilities. According to our study, some case-study firms were able to recognise and exploit human capital better and more successfully than other firms in the sample. Evidently, these firms are overall more successful.

\section{References}

Adner, R./Helfat, C.E. (2003): Corporate effects and dynamic managerial capabilities, in: Strategic Management Journal, 24, 10, 1011-1025.

Ambrosini, V./Bowman, C. (2009): What are dynamic capabilities and are they a useful construct in strategic management, in: International Journal of Management Reviews, 11, 1, 29-49.

Ambrosini, V./Bowman, C./Collier, N. (2009): Dynamic capabilities: An exploration of how firms renew their resource, in: British Journal of Management, 20, S1, 9-24.

Arend, R.J./Bromiley, P. (2009): Assessing the dynamic capabilities view: Spare change, everyone, in: Strategic Organization, 7, 75, 75-90.

Augier, M./Teece, D.J. (2009): Dynamic capabilities and the role of managers in business strategy and economic performance, in: Organization Science, 20, 2, 410-421. 
Banuls, V.A./Salmeron, J.L. (2008). Foresighting areas in the information technology industry, in: Technovation, 28, 3, 103-111.

Barney, J.B. (1991): Firm resources and sustained competitive advantage, in: Journal of Management, 17, 1, 99-120.

Barney, J.B./Clark, D.N. (2007): Resource-based theory: Creating and sustaining competitive advantage. Oxford: University Press.

Barreto, I. (2010): Dynamic capabilities: A review of past research and an agenda for the future, in: Journal of Management, 36, 1, 256-280.

Birchall, D./Tovstiga, G. (2005): Capabilities for strategic advantage: Leading through technological innovation. Basingstoke: Palgrave Macmillan.

Breznik, L./Lahovnik, M. (2012): Innovation capability as a source of competitive advantage in Slovenian information technology firms, in: TTEM: Technics Technologies Education Management, 7, 3, 1132-1144.

Bruni, S.D./Verona, G. (2009): Dynamic marketing capabilities in science-based firms: An exploratory investigation of the pharmaceutical industry, in: British Journal of Management, 20, 101-117.

Cohen, W.M./Levinthal, D.A. (1990): Absorptive capacity: A new perspective on learning and innovation, in: Administrative Science Quarterly, 35, 1, 128-152.

Culpan, R. (2008): The role of strategic alliances in gaining sustainable competitive advantage for firms, in: Management Revue, 19, 1/2, 94-105.

Cyert, R.M./March, J.G. (1963): A behavioural theory of the firm. Oxford: Blackwell Press.

Day, G. (1994): The capabilities market-driven organizations, in: Journal of Marketing, 58, 3, $37-52$.

DiStefano, G./Peteraf, M./Verona, G. (2010): Dynamic capabilities deconstructed: A bibliographic investigation into the origins, development, and future directions of the research domain, in: Industrial and Corporate Change, 19, 4, 1187-1204.

Eisenhardt, K.M. (1989): Building theories from case studies, in: Academy of Management Review, 14, 4, 532-550.

Einsehardt, K.M./Martin, J. (2000): Dynamic capabilities: What are they, in: Strategic Management Journal, 21, 10/11, 1105-1121.

Grant, R.M. (1996): Toward a knowledge-based theory of the firm, in: Strategic Management Journal, 17, 4, 109-122.

Harreld, J.B./O'Reilly, C.A./Tushman, M.L. (2007): Dynamic Capabilities at IBM: Driving strategy into action, in California Management Review, 49, 4, 21-43.

Helfat, C.E./Peteraf, M.A. (2009): Understanding dynamic capabilities: Progress along a developmental path, in: Strategic Organization, 7, 91, 91-102.

Hii, J./Neely, A. (2000): Innovative Capacity of Firms: On Why Some Firms are More Innovative Than Others. Conference Paper, 7th International Annual EurOMA Conference 2000, Ghent.

Itami, H./Roehl, T.L. (1987): Mobilizing invisible assets. Cambridge, MA: Harvard University Press. 
Jie, Z./Han, L./Ziegelmayer, J. (2009): Resource or capability? A dissection of SMEs' IT infrastructure flexibility and its relationship with IT responsiveness, in: Journal of Computer Information Systems, 50, 1, 46-53.

Kamoche, K./Mueller, F. (1998): Human resource management and the appropriationlearning perspective, in: Human Relations, 51, 8, 1033-1060.

Katkalo, V.S./Pitelis, C.N./Teece, D.J. (2010): Introduction: On the nature and scope of dynamic capabilities, in: Industrial and Corporate Change, 19, 4, 1175-1186.

Kor, Y.Y./Mahoney, J.T. (2005): How dynamics, management, and governance of resource deployments influence firm-level performance, in: Strategic Management Journal, 26, $5,489-496$.

Lado, A.A./Wilson, M.C. (1994): Human resource systems and sustained competitive advantage: A competency-based perspective, in: Academy of Management Review, 19, 4, 699-727.

Leonard-Barton, L.D. (1990): A dual methodology for case studies: Synergistic use of a longitudinal single site with replicated multiple sites, in: Organization Science, 1, 3, 248266.

Moliterno, T./Wiersema, M.F. (2007): Firm performance, rent appropriation, and the strategic resource divestment capability, in: Strategic Management Journal, 28, 1, 1065-1087.

Melville, N./Kraemer, K./Gurbaxani, V. (2004): Review: Information technology and organizational performance: An integrative model of IT business value, in: MIS Quarterly, $28,2,283-322$.

Nelson, R.R./Winter, S.G. (1982): An evolutionary theory of economic change. Cambridge MA: Harvard University Press.

Newbert, S.L. (2007): Empirical research on the resource based view of the firm: An assessment and suggestions for future research, in: Strategic Management Journal, 28, 2, 121-146.

Saldana, J. (2009): The coding manual for qualitative researchers. London: Sage Publications.

Song, M./Droge, C./Hanvanich, S./Calantone, R. (2005): Marketing and technology resource complementarity: An analysis of their interaction effect in two environmental contexts, in: Strategic Management Journal, 26, 3, 259-276.

Teece, D. (2009): Dynamic capabilities and strategic management: Organizing for innovation and growth. Oxford, New York: Oxford University Press.

Teece, D. (2007): Explicating dynamic capabilities: The nature and microfoundations of (sustainable) enterprise performance, in: Strategic Management Journal, 28, 13, 13191350 .

Teece, D./Pisano, G. (1994): The dynamic capabilities of firms: An introduction. Laxenburg, Austria: International Institute for Applied Systems Analysis (IIASA).

Teece, D./Pisano, G./Shuen, A. (1990): Firm capabilities, resources and the concept of strategy, Economic analysis and policy working paper EAP 38, University of California.

Teece, D./Pisano, G./Shuen, A. (1997): Dynamics capabilities and strategic management, in: Strategic Management Journal, 18, 7, 509-533. 
Schumpeter, J.A. (1934): Theory of economic development. Cambridge, MA: Harvard University Press.

Pierce, L./Teece, D.J. (2005): The Behavioural, Evolutionary, and Dynamic Capabilities Theories of the Firm: Retrospective and Prospective, retrieved from: http://apps.olin. wustl.edu/faculty/pierce/Research_files/PierceTeece.pdf (accessed 29. Nov. 2012).

Porter, M.E. (1985): Competitive advantage: Creating and sustaining superior performance. New York: The Free Press.

Prahalad, C.K./Hamel, G. (1990): The core competence of the corporation, in: Harvard Business Review, 68, 3, 79-91.

Priem, R.L./Butler, J.E. (2001): Is the resource-based view a useful perspective for strategic management research, in Academy of Management Review, 26, 1, 22-40.

Rothwell, R./Dodgson, M. (1991): External linkages and innovation in small and mediumsized enterprises, in: R\&D Management, 21, 2, 125-138.

Rosenbloom, R.S. (2000): Leadership, capabilities, and technological change: The transformation of NCR in the electronic era, in: Strategic Management Journal, 21, 10/11, 1083-1103.

Rouse, M.J./Daellenbach, U.S. (1999): Rethinking research methods for the resource-based perspective: Isolating sources of sustainable competitive advantage, in: Strategic Management Journal, 20, 5, 487-494.

Rindova, V.P./Kotha, S. (2001): Continuous morphing: Competing through dynamic capabilities, form, and function, in: Academy of Management Journal, 44, 6, 1263-1280.

Rubin, H.J./Rubin, I.S. (2005): Qualitative interviewing. The art of hearing data. Thousand Oak, California: Sage Publications.

Stirling-Attride, J. (2001): Thematic networks: An analytical tool for qualitative research, in: Qualitative Research, 1, 3, 385-405.

Tidd, J./Bessant, J. (2009): Managing innovation, integrating technological, market and organizational change. Chichester, England: John Wiley \& Sons.

Turban, E./Leidner, D./McLean, E./Wetherbe, J. (2008): Information technology for management: Transforming organizations in the digital economy. Hoboken, NJ: Wiley.

Venkatraman, N./Ramanujam, V. (1986): Measurement of business performance in strategy research: A comparison of approaches. Academy of Management Review, 11, 4, 801814.

Verloop, J. (2004): Insights in innovation: Managing innovation by understanding the laws of innovation. Amsterdam: Elsevier.

Wang, C.L./Ahmed, P.K. (2007): Dynamic capabilities: A review and research agenda, in: International Journal of Management Reviews, 9, 1, 31-51.

Wernerfelt, B. (1984): A resource-based view of the firm, in: Strategic Management Journal, $5,2,171-180$.

Wernerfelt, B./Montgomery, C.A. (1988): Tobin's q and the Importance of Focus in Firm Performance, in: The American Economic Review, 78, 1, 246-250.

Wiggins, R.R./Ruefli, W.T. (2005): Schumpeter's ghost: Is hypercompetition making the best of times shorter, in: Strategic Management Journal, 26, 10, 887-911. 
Winter, S.G. (2003): Understanding dynamic capabilities, in: Strategic Management Journal, 24, 10, 991-995.

Winter, S.G. (1975): Optimization and evolution in theory of the firm, in Day, R./Groves, T. (eds.): Adaptive economic models, New York: Academic Press, 73-118.

Yin, R.K. (2009): Case study research: Design and methods (4th ed.). Thousand Oaks, California: Sage Publications.

Zahra, S.A./Sapienza H./Davidsson, P. (2006): Entrepreneurship and dynamic capabilities: A review, model and research agenda, in: Journal of Management Studies, 43, 4, $917-$ 955.

Zollo, M./Winter, S. (2002): Deliberate learning and the evolution of dynamic capabilities, in: Organization Science, 13, 3, 339-351.

Zott, C. (2003): Dynamic capabilities and the emergence of intra-industry differential firm performance: Insights from a simulation study, in: Strategic Management Journal, 24, 2, 97-125. 


\section{Appendix}

Appendix 1: Overview of the practices that underpin dynamic capabilities in the case-study firm Beta

\begin{tabular}{|c|c|c|c|}
\hline \multirow[b]{2}{*}{ Capabilities } & \multicolumn{3}{|c|}{ Composition of dynamic capabilities } \\
\hline & (1) SENSE & (2) SEIZE & (3) RECONFIGURE \\
\hline $\begin{array}{l}\text { Managerial } \\
\text { capability }\end{array}$ & $\begin{array}{l}\text { Open communication } \\
\text { (inside and outside the firm) } \\
\text { Openness } \\
\text { Knowledge absorption: envi- } \\
\text { ronments, industries, and their } \\
\text { dynamics }\end{array}$ & $\begin{array}{l}\text { Long-term partnerships: } \\
\text { customers, partners and em- } \\
\text { ployees } \\
\text { Outsourcing } \\
\text { Business model development } \\
\text { Networking } \\
\text { Accepting diversity }\end{array}$ & $\begin{array}{l}\text { Development of key capabili- } \\
\text { ties at the firm level } \\
\text { Development of employees } \\
\text { and management of key capa- } \\
\text { bilities } \\
\text { Build on strategic orientation: } \\
\text { "At the right place and at the } \\
\text { right time. } \\
\text { Being the first-mover." } \\
\text { Key-business process } \\
\text { reengineering } \\
\text { Teamwork (project-based } \\
\text { work) } \\
\text { Reward system } \\
\text { Building an appropriate organ- } \\
\text { isational structure and culture } \\
\text { New top management team }\end{array}$ \\
\hline $\begin{array}{l}\text { Marketing } \\
\text { capability }\end{array}$ & $\begin{array}{l}\text { Networking - individual level } \\
\quad \text { (markets, competitors) } \\
\text { Employees as part of the mar- } \\
\text { keting process }\end{array}$ & $\begin{array}{c}\text { Goal-oriented networking - } \\
\text { individual level } \\
\text { (clientele - additional pro- } \\
\text { jects, potential customers - } \\
\text { new business projects) } \\
\text { Employees playing an active } \\
\text { part in marketing activi- } \\
\text { ties/process } \\
+ \text { business analysts and pro- } \\
\text { ject managers (planned ac- } \\
\text { tivities) }\end{array}$ & $\begin{array}{l}\text { Improving customers' loyalty } \\
\text { and satisfaction } \\
\text { Partnerships: customers, sup- } \\
\text { pliers, competitors } \\
\\
\text { Active long-term } \\
\text { partnerships }\end{array}$ \\
\hline
\end{tabular}




\begin{tabular}{|c|c|c|c|}
\hline \multirow[b]{2}{*}{ Capabilities } & \multicolumn{3}{|c|}{ Composition of dynamic capabilities } \\
\hline & (1) SENSE & (2) SEIZE & (3) RECONFIGURE \\
\hline $\begin{array}{c}\text { Technological } \\
\text { capability }\end{array}$ & $\begin{array}{l}\text { Networking - individual level } \\
\text { (suppliers) } \\
\text { Sensing: technological devel- } \\
\text { opment, specifically in the IT } \\
\text { area }\end{array}$ & $\begin{array}{l}\text { Networking - individual level } \\
\text { (selected suppliers) } \\
\text { Seizing opportunities for } \\
\text { exploiting new/improved } \\
\text { technology and knowledge - } \\
\text { in line with a business model }\end{array}$ & $\begin{array}{c}\text { Reconfiguring the resource } \\
\text { base: products/services in line } \\
\text { with technological develop- } \\
\text { ment } \\
\text { and market demands }\end{array}$ \\
\hline $\begin{array}{c}\text { R\&D } \\
\text { capability }\end{array}$ & $\begin{array}{l}\text { Networking - individual level } \\
\text { (potential partners) } \\
\text { Sensing: markets, competitors } \\
\text { Benchmarking (competitors) } \\
\text { Activities/collaboration with } \\
\text { R\&D organisations }\end{array}$ & $\begin{array}{l}\text { Seizing opportunities in the } \\
\text { market (tapping the potential } \\
\text { synergy) } \\
\text { Benchmarking (competitors, } \\
\text { markets) - searching for } \\
\text { diversity } \\
\text { Known and unknown } \\
\text { environments (resource base) }\end{array}$ & $\begin{array}{l}\text { Adopting new/improved } \\
\text { knowledge and technologies } \\
\text { and transforming them into } \\
\text { market-oriented solutions } \\
\text { (knowledge transfer) } \\
\text { Improving the effectiveness } \\
\text { of business processes }\end{array}$ \\
\hline $\begin{array}{l}\text { Innovation } \\
\text { capability }\end{array}$ & $\begin{array}{l}\text { Innovation activities as a } \\
\text { key/dominant part of business } \\
\text { processes (not formalised) }\end{array}$ & $\begin{array}{l}\text { Market-oriented innovations } \\
\text { Customers playing an active } \\
\text { part in innovation activities } \\
\text { Starts - more innovative } \\
\text { employees }\end{array}$ & $\begin{array}{c}\text { Innovation group } \\
\text { Innovation-oriented leaders } \\
\text { Transforming new ideas into } \\
\text { new/improved market-oriented } \\
\text { innovations } \\
\text { Stimulation/development of } \\
\text { creativity and innovation } \\
\text { Reward system }\end{array}$ \\
\hline
\end{tabular}




\begin{tabular}{|c|c|c|c|}
\hline \multirow[b]{2}{*}{ Capabilities } & \multicolumn{3}{|c|}{ Composition of dynamic capabilities } \\
\hline & (1) SENSE & (2) SEIZE & (3) RECONFIGURE \\
\hline $\begin{array}{l}\text { Human re- } \\
\text { source capab- } \\
\text { ility }\end{array}$ & $\begin{array}{l}\text { Sensing a lack of knowledge } \\
\text { and a need for new/improved } \\
\text { knowledge in the } \\
\text { existing knowledge base } \\
\text { Sensing opportunities: } \\
\text { clientele, partners, } \\
\text { professional conferences }\end{array}$ & $\begin{array}{l}\text { Self-dependent seizing and } \\
\text { identifying of needs for spe- } \\
\text { cific knowledge and } \\
\text { expertise } \\
\text { (in line with a business mod- } \\
\text { el) } \\
\text { New recruitments } \\
\text { Employee self-directed } \\
\text { learning } \\
\text { Networking - partnerships } \\
\text { Time for creativity }\end{array}$ & $\begin{array}{l}\text { Knowledge and experiences } \\
\text { transfer } \\
\text { Mentorships } \\
\text { Internal learning system } \\
\text { Learning from failures (trial } \\
\text { and error) } \\
\text { Reward system } \\
\text { Creating/developing 'the } \\
\text { best/dream team' in the firm } \\
\text { Employees' satisfaction }\end{array}$ \\
\hline
\end{tabular}

Appendix 2: Selected indicators and results among the case-study firms for the 2006-2011 period

\begin{tabular}{|c|c|c|c|c|c|}
\hline \multicolumn{6}{|c|}{ Case-study firms } \\
\hline Alpha & Beta & Delta & Gamma & Epsilon & Zeta \\
\hline $\begin{array}{c}\text { Founded in the } \\
1990 \mathrm{~s}\end{array}$ & $\begin{array}{l}\text { Founded in the } \\
1970 \text { s as a spin- } \\
\text { off of a university } \\
\text { research institute }\end{array}$ & $\begin{array}{c}\text { Founded in } 1999 \\
\text { as a spin-off a } \\
\text { large industrial } \\
\text { firm }\end{array}$ & $\begin{array}{c}\text { Founded in the } \\
1990 \mathrm{~s}\end{array}$ & $\begin{array}{c}\text { Founded in the } \\
1980 \mathrm{~s}\end{array}$ & $\begin{array}{c}\text { Founded in the } \\
\text { 1990s; nine } \\
\text { years ago it was } \\
\text { taken over by a } \\
\text { large state- } \\
\text { owned firm }\end{array}$ \\
\hline $\begin{array}{l}110 \text { employees } \\
\text { in } 2011\end{array}$ & $\begin{array}{l}55 \text { employees } \\
\text { in } 2011\end{array}$ & $\begin{array}{l}74 \text { employees } \\
\text { in } 2011\end{array}$ & $\begin{array}{l}70 \text { employees } \\
\text { in } 2011\end{array}$ & $\begin{array}{l}63 \text { employees } \\
\text { in } 2011\end{array}$ & $\begin{array}{l}140 \text { employees } \\
\text { in } 2011\end{array}$ \\
\hline $\begin{array}{l}\text { earnings of } \\
€ 11 \text { million in } \\
2011\end{array}$ & $\begin{array}{l}\text { earnings of } € 4 \\
\text { million in } 2011\end{array}$ & $\begin{array}{l}\text { earnings of } € 6 \\
\text { million in } 2011\end{array}$ & $\begin{array}{l}\text { earnings of } € 7 \\
\text { million in } 2011\end{array}$ & $\begin{array}{l}\text { earnings of } € 4.5 \\
\text { million in } 2011\end{array}$ & $\begin{array}{l}\text { earnings of } € 25 \\
\text { million in } 2011\end{array}$ \\
\hline
\end{tabular}




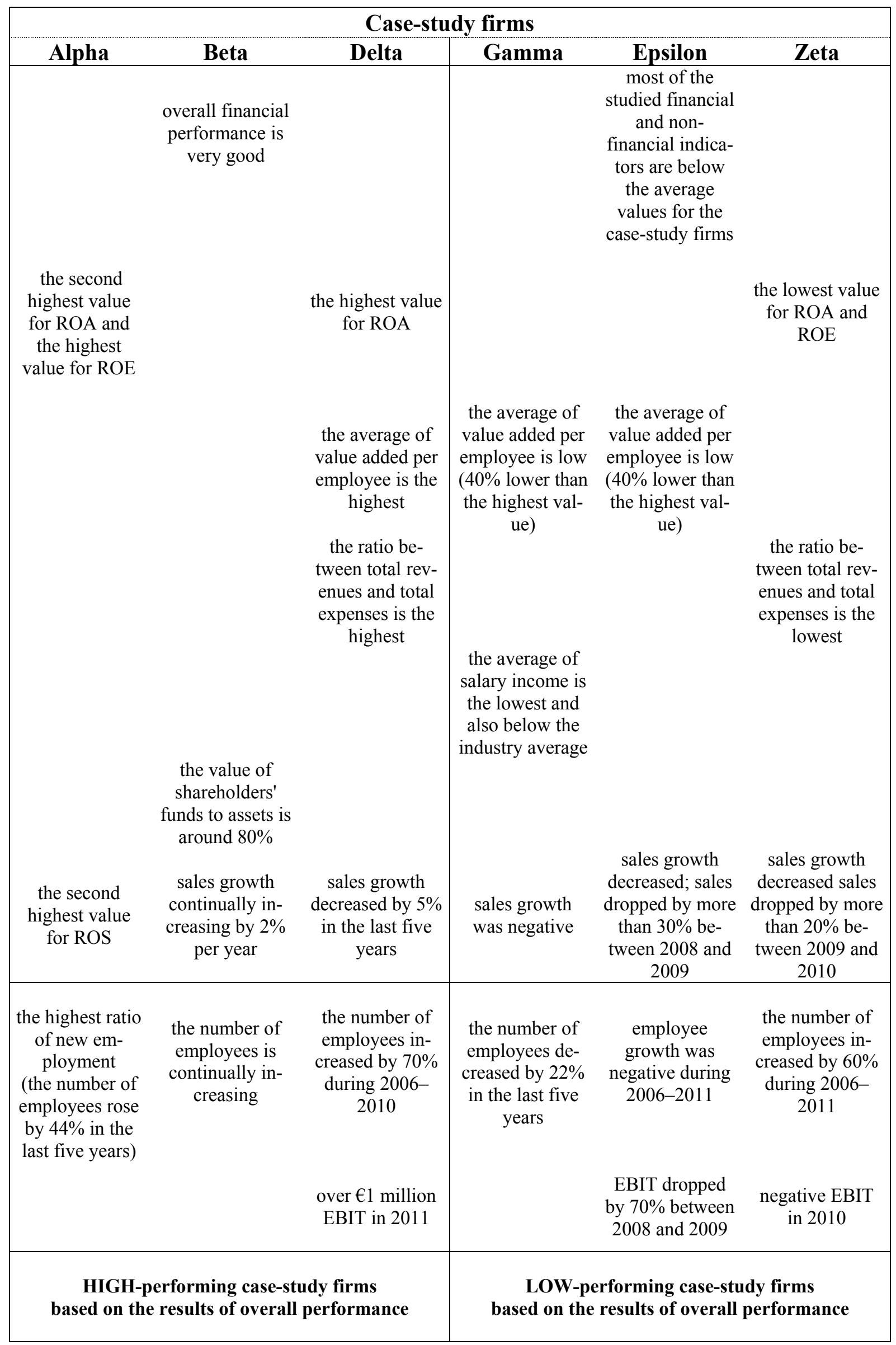

